\title{
God kvalitet i \\ livestreamet \\ undervisning \\ - fra underviserens point of view
}

\section{Vibe Alopaeus Jelsbak}

Lektor og projektmedarbejder

Lektor på Bioanalytikeruddannelsen og medarbejder i

Center for læring og it, VIA University College

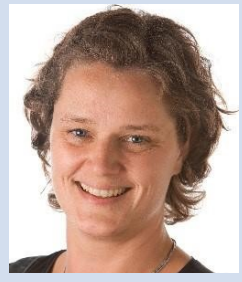

\section{Lillian Buus}

Ph.d. og Specialkonsulent

Pædagogisk it-designer i Enheden for Læringsdesign under Forskning- og udvikling i EVU, VIA University

College

\section{Jonas Thorsen}

\section{Lektor}

Lektor på Bioanalytikeruddannelsen, VIA University College
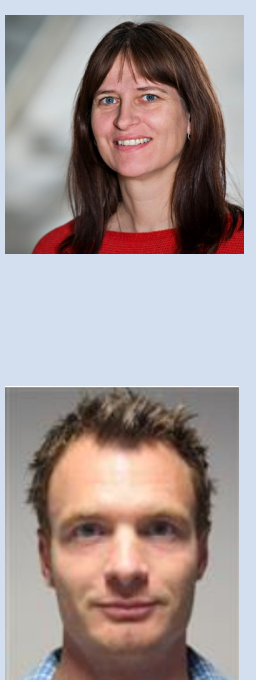


\section{English abstract}

The bachelor programme in biomedical laboratory technology at VIA Faculty of Health Sciences has established an educational programme that combines traditional and live-streamed teaching. A new technical setup has been designed to support interaction and dialogue. The aim of this study is to evaluate how the live-streamed teaching affects the interaction in a setting optimized for pedagogical solutions using dialogue. The results indicate that the teachers prefer interaction with students using traditional pedagogical designs and a low level of technical complexity. They further show that teachers are dependent on visual contact with students in order to establish dialogue and they insist on dialogue as a central element of good teaching.

\section{Abstract}

Bioanalytikeruddannelsen, VIA University College i Aarhus, har etableret et undervisningskoncept, som kombinerer traditionel og livestreamet undervisning.

Teknologiske udfordringer og begrænsninger i dialog er blandt de vigtigste udfordringer, eftersom undervisere anvender dialog og diskussion $\mathrm{i}$ traditionel undervisning. I artiklen præsenteres uddannelsens fornyede rammer og tekniske løsninger for livestreamingen og de didaktiske design, som disse forventes at understøtte, diskuteres. Resultaterne indikerer, at undervisningen ikke redidaktiseres i livestreamet undervisning, men er påvirket af undervisernes ønske om mulighed for dialog gennem anvendelse af kendte undervisningsformer og et lavt niveau af teknisk kompleksitet. Resultaterne viser desuden, at underviserne er afhængig af visuel kontakt med studerende for at etablere god undervisning baseret på dialog.

\section{Baggrund og rammer for netbaseret undervisning på VIA Bioanalytikeruddannelsen}

VIA Bioanalytikeruddannelsen i Aarhus har siden 2009 udbudt dele af undervisningen som netbaseret undervisning. Uddannelsen har et stort geografisk optageområde, og erfaringsmæssigt har tilbuddet om netbaseret undervisning udvidet rekrutteringsgrundlaget og bidraget til øget fastholdelse, blandt andet fordi studerende med bopæl langt fra Aarhus har forbedrede muligheder for at blive boende i deres nærområde, men samtidig deltage i studierne. Den netbaserede undervisning gennemføres i form af livestreaming, hvor de studerende en til to dage om ugen kan vælge, om de vil deltage i undervisningen ved fremmøde eller deltage via deres computer i livestreamingen. Den enkelte studerende har dermed mulighed for på dag-til-dag basis at planlægge, hvorvidt deltagelse $\mathrm{i}$ undervisningen sker ved fremmøde eller online. Den praktiske gennemførsel af undervisningen er uafhængig af fordelingen mellem 
antallet af net- og fremmødestuderende. Strategisk har uddannelsen besluttet, at alle undervisere på bioanalytikeruddannelsen skal kunne gennemføre livestreamet undervisning på lige vilkår, som ved traditionelt fremmøde. Det betyder, at der ikke ydes økonomisk/ressourcemæssig kompensation til f.eks. forberedelse, planlægning eller lign.

Indtil foråret 2015 anvendte uddannelsen en mobil, lokaleuafhængig løsning, hvor video og lyd fra undervisningslokalet blev streamet via et transportabelt $360^{\circ}$-kamera, tavleundervisning blev streamet ved anvendelse af en interaktiv tavle, og elektroniske præsentationer ( $\mathrm{fx}$ PowerPoint) blev streamet via skærmdeling fra underviserens PC ved anvendelse af Microsoft Skype for Business som mødesoftware. De indledende erfaringer viste, at et stort og stigende antal studerende benyttede sig af tilbuddet om at deltage hjemmefra via streaming. Underviserne oplevede den livestreamede undervisning som udfordrende og væsentlig forskellig fra den traditionelle tilstedeværelsesundervisning.

I perioden 2012 til 2013 blev der gennemført et forskningsprojekt, som undersøgte livestreamingens betydning for undervisernes didaktiske praksis (Ørngreen, Levinsen, Jelsbak, Bendsen, \& Møller, 2013). Undersøgelsen var baseret på data fra optagede video-observationer, et 'question of the day' til de studerende (Ørngreen, Jørgensen, \& Noesgaard, 2016), og interviews med undervisere. Projektet dokumenterede, at de livestreamede lektioner i høj grad bar præg af underviser-monolog (PowerPoints og envejskommunikation/instruktion) på trods af, at de samme undervisere anvender dialogbaseret undervisning i den øvrige undervisning. Projektet identificerede teknologiske begrænsninger, som den primære årsag til dette. Den manglende visuelle kontakt med de studerende, som deltog via livestreaming, blev af underviserne opfattet som en hindring for dialog. Studerende, som deltog hjemmefra via streaming, havde ofte svært ved at høre og skelne samtaler blandt studerende i undervisningslokalet. Studerende opfattede det som grænseoverskridende at bryde ind og tale til klassen via lokalets højtalere. Et andet centralt fund var, at underviserne oplevede teknologien som sårbar og kompliceret at håndtere. På trods af at underviserne på Bioanalytikeruddannelsen har et relativt højt IT-kompetenceniveau sammenlignet med andre uddannelser i VIA (VIA University College, 2015), anså underviserne risikoen for tekniske fejl i forbindelse med streaming som en væsentlig stressfaktor og forhindring for velfungerende undervisning.

Internationalt er der lavet en del forskning omkring brug af videostreaming i undervisningen, samt hvordan video kan indgå i 'distance education' og den påvirkning det har, når undervisning foregår livestreamet (Klibanov, Dolder, Anderson, Kehr, \& Woods, 2018; Scarbrough, 2015). En stor del af de nyere artikler omkring videostreaming i undervisningen har fokus på 
studerende og deres læring, men enkelte artikler har fokus på underviserne og deres rolle i tilrettelæggelsen af denne form for undervisning (Rehn, Maor, \& McConney, 2017; Wang, Quek, \& Hu, 2017). Det kunne derfor være interessant at have fokus på underviserne, og derfor undersøges og diskuteres det i artiklen:

- Hvordan de didaktiske og teknologiske udfordringer opleves af underviserne, og hvordan påvirkes dialog og interaktion i livestreamet undervisning?

- Herunder diskuteres, hvordan dialog og interaktion i livestreamet undervisning bør tilrettelægges og afvikles, så god kvalitet i undervisningen sikres.

Artiklen bidrager med generel diskussion af forståelsen for hvad der skaber god undervisning i et livestream-setup fra undervisernes perspektiv. Gennem undersøgelsen er også samlet data om de studerendes oplevelse af deltagelse, som præsenteres i separat udgivelse (Jelsbak, Buus, Thorsen, Bendsen, \& Ørngreen, 2017).

\section{Dedikeret lokale til livestreaming af undervisning Det teknologiske setup}

Med henblik på at afhjælpe teknologiske udfordringer udstyrede uddannelsen i foråret 2015 et dedikeret lokale til livestreaming med henblik på anvendelse i daglig praksis, hvilket betragtes som en kvalitet i sammenligning med undersøgelser, der etableres med en afgrænset projektøkonomi i en projektperiode (Buhl, 2015; B. Meyer, 2015).

Lokalet er indrettet så der tilbydes en simpel og robust brugerflade for underviseren, og muligheden for dialogbaseret undervisning forbedres. Dette er søgt gennem udstyring af lokalet med dobbelt videosignal ud fra henholdsvis et fastmonteret whiteboard-kamera og underviserens PC. Der er desuden forbedret lydopsætning i form af fastmonterede, loftshængte mikrofoner. Endelig er der monteret en LCD-skærm, som viser video af de studerende via deres webkamera. Det betyder at underviseren ved undervisningens start, som det eneste, skal 1) oprette et onlinemøde for holdet i Outlook og 2) starte streamingen fra lokalet med en enkelt berøring på en touchskærm (fig. 1A).

Anvendes der kun tavleundervisning og dialog mellem studerende og underviser, skal der ikke gøres yderlige, da lokalets mikrofoner tændes automatisk ved opstart, og det fastmonterede kamera er forhåndsindstillet til at filme whiteboardtavlen. Skal underviseren præsentere elektronisk indhold (fx PowerPoint), skal der tilsluttes to kabler til underviserens egen PC (fig. 1A), som det er kendt fra øvrige undervisnngsloka ler. Denne 
relativt simple procedure er muliggjort af et relativt kompliceret teknologisk setup, som skjuler sig "under overfladen" (fig. 1B).

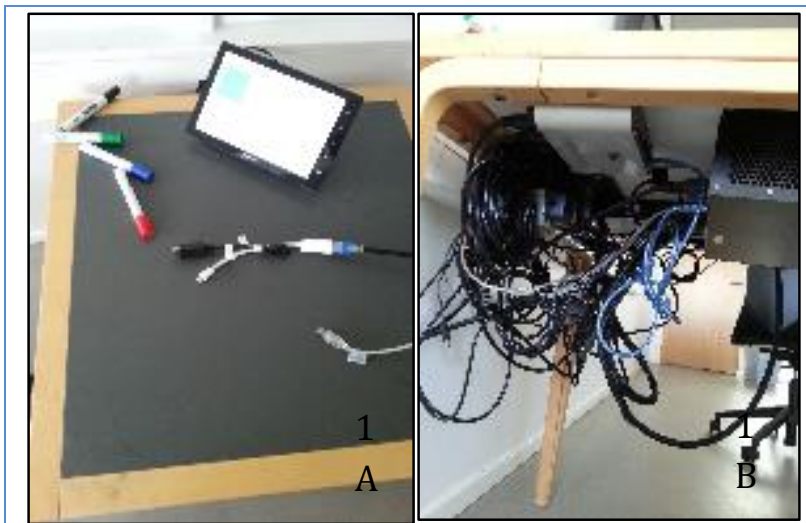

Figur 1. 1A: Hvad underviseren skal forholde sig til af teknik og 1B: Hvad der er "under overfladen", for at underviseren kan have en simpel "brugerflade"

Når onlinemødet er startet, kan underviseren og de fremmødte studerende se webcamsignal fra fem hjemmestuderende på LCD-skærmen på bagvæggen i lokalet. De studerende, som deltager via livestream, kan se videosignal fra det fastmonterede kamera samt skærmdeling fra underviser eller medstuderendes PC (Fig. 2A + 2B).

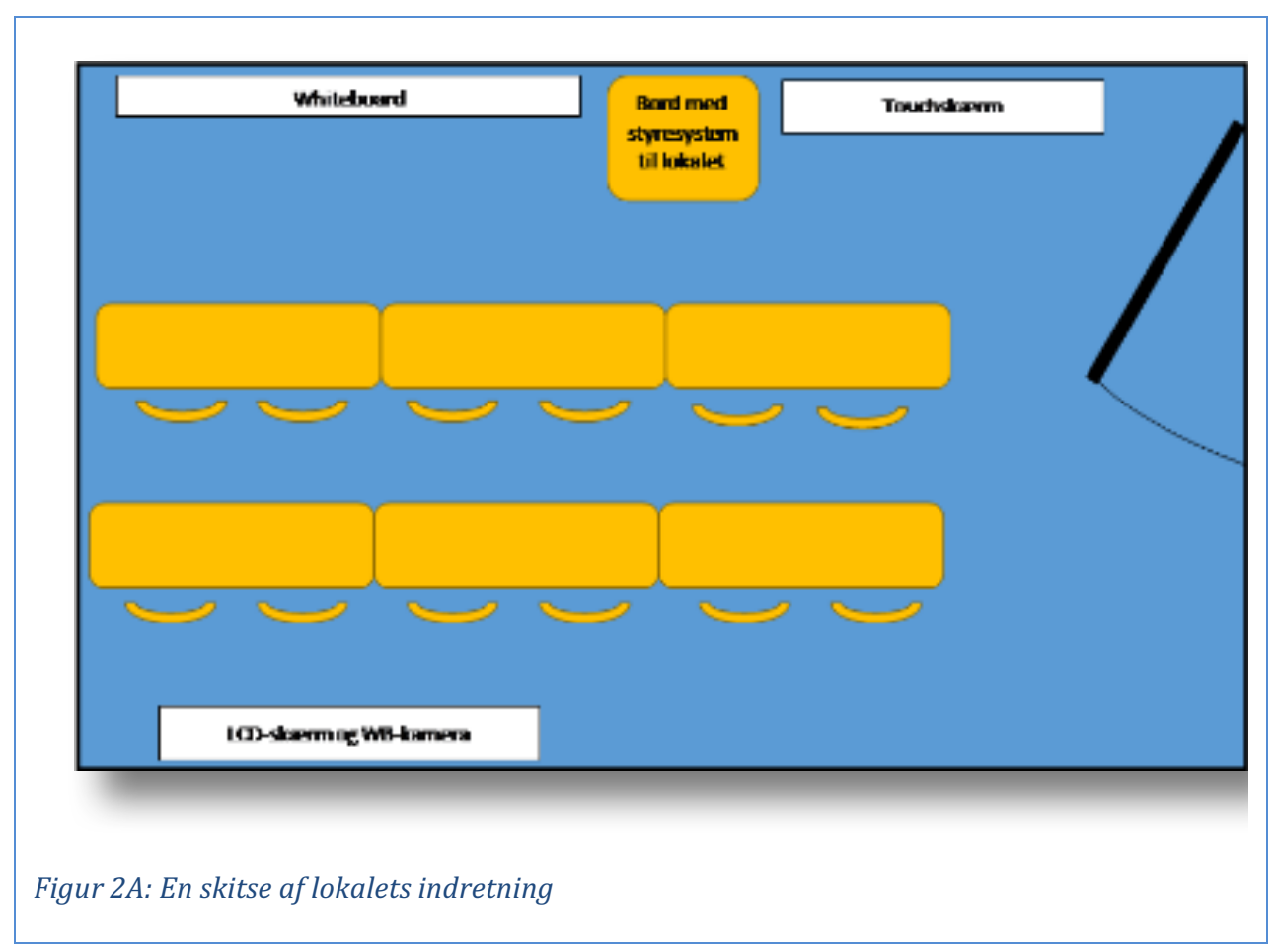




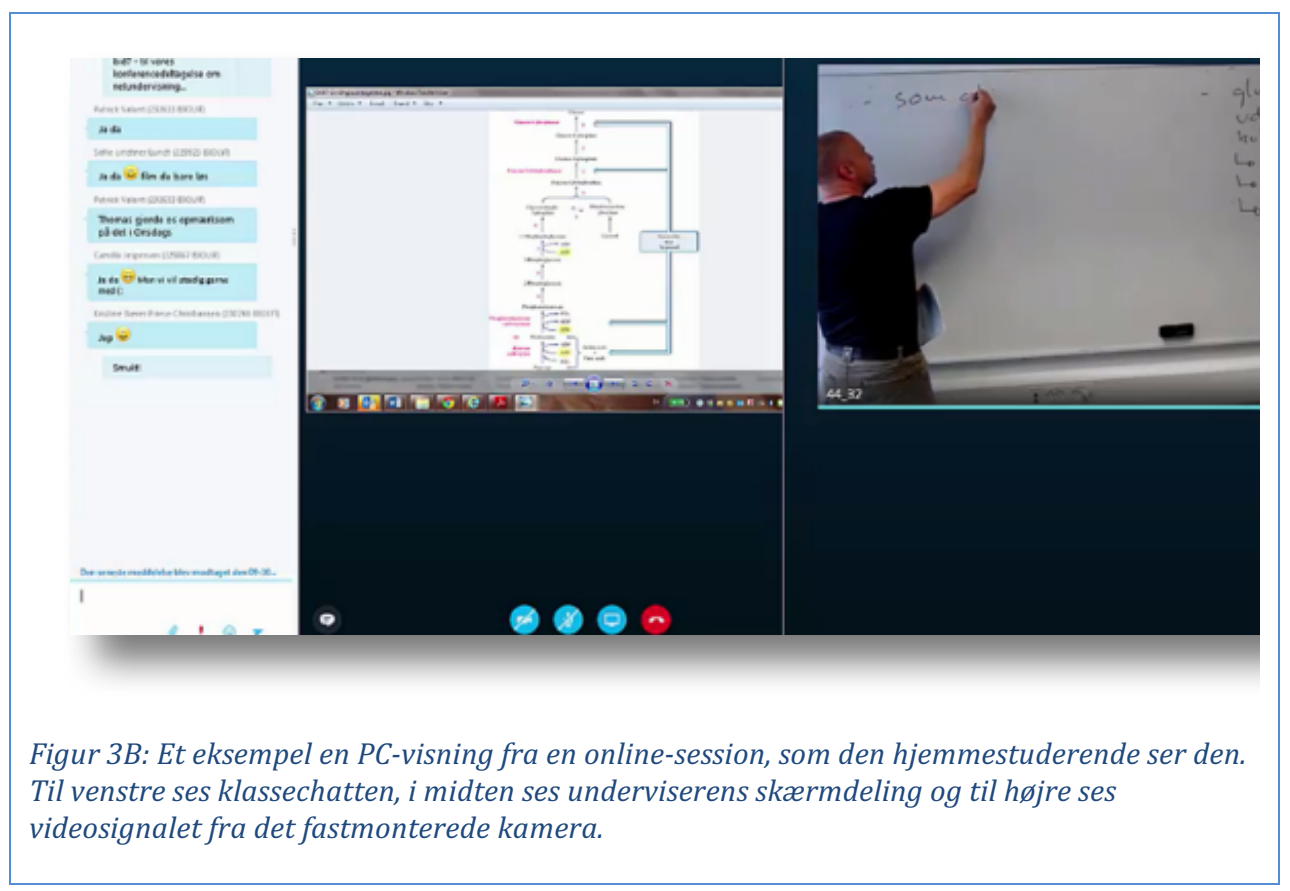

\section{Teoretisk fundament}

\section{“God undervisning"... hvordan det?}

Begrebet "god undervisning" hænger sammen med undervisernes valg af didaktisk design. I sin bog om "CrossActionSpaces" beskriver Jahnke (2016), hvordan undervisning med internettets indtog har givet de lærende en nem og hurtig adgang til information. Herved udfordres den traditionelle indretning af klasserummet som et auditorie, idet fremtidens klasserum i højere grad vil være organiseret med fokus på interaktion og samarbejde ("crossactions") (Jahnke, 2016, s. 4-7). Underviserens rolle bliver herved at designe rammerne for læring, som fremmer CrossActions mellem de lærende, uafhængigt af hvor de fysisk er placeret. Når det fysiske rum kombineres med et onlinerum, bliver undervisningsrummet til et "CrossActionSpace". Den læring, der sker i disse rum, sker ifølge Jahnke (2016) gennem lærende-centreret refleksiv kommunikation (Jahnke, 2016, pp.12-15). Dette understøttes af Nystrand (1997), der beskriver hvordan kvaliteten i studerendes læring er tæt forbundet med kvaliteten i klasserumssamtalen ud fra måden studerende tænker og lærer på. Dette er afhængig af hvordan underviserne responderer på de studerendes svar i en samtale (ibid.). Der er påvist en stærk signifikant sammenhæng mellem det faglige niveau, de 
studerende opnår og i hvor høj grad klasserumssamtalen fjerner sig fra den traditionelle form for undervisning med monologisk samtale, hvor en underviser Initierer med et spørgsmål, får et Respons fra studerende og Evaluerer herefter korrektheden af pågældende respons, "IRE" (Nystrand, Wu, Gamoran, Zeiser, \& Long, 2003).

Meyer (2005) oplister "ti gode råd om god undervisning", se tabel 1.

Tabel 110 gode råd om god undervisning (H. Meyer, 2005).

\begin{tabular}{|l|}
\hline 1. Rød tråd og struktur. \\
\hline 2. Brug tiden på læring \\
\hline 3. Giv eleverne lyst til at deltage \\
\hline 4. Aktiver det, eleverne ved i forvejen \\
\hline 5. Sæt ord på, hvad eleverne skal lære og hvorfor \\
\hline 6. Varier metoderne \\
\hline 7. Tag individuelle hensyn \\
\hline 8. Træn - igen og igen og målrettet \\
\hline 9. Fysiske rammer \\
\hline 10. Sig, hvad du forventer \\
\hline
\end{tabular}

"God undervisning" oversat til en professionsdidaktisk kontekst, kan med hensyn til punkt 1 og 4 tolkes som studerendes oplevelse af sammenhæng mellem elementer i uddannelsen, både de enkelte faglige områder og også i teori-praksis-relationen (Landbo, Hedegaard, Nielsen, \& Nielsen, 2010). Dialogens niveau og rammesætning kan fremme, at studerende motiveres og engageres, hvorved sandsynligheden for at de kan inddrages i dialogisk diskussion øges (punkt 3, 6, 7 og 10), hvilket der også argumenteres for hos Nystrand et al (2003). Undervisningen rummer en dialog, styret af underviser, og som med basis i en interesse for den enkelte studerende også er tilpasset den enkelte studerende. Hertil lægges, at undervisningen tilpasses de rammer, der er givet af både fysisk og organisatorisk karakter, 
som fx målstyret undervisning, flipped learning og livestreaming af undervisning (Punkt 2, 5, 8 og 9).

\section{Interaktion i livestreamet undervisning - en udfordring?}

De centrale temaer ift. diskussion af undervisernes oplevelse af livestreamet undervisning omhandler didaktik og kommunikation, og hvordan disse er påvirket af teknologien.

Mathiasen (2011) beskriver undervisning som "intenderet kommunikation", der kan forstyrres ved, at opmærksomheden flyttes fra indholdet til selve kommunikationen.

Gennem anvendelse af Bakhtins epitemiologiske skelnen mellem monologisk og dialogisk diskussion, har Nystrand et al. (2003) identificeret og kvantificeret sekvenser af underviser-studerende-interaktion og klassificeret denne ift. i hvor høj grad der var pædagogisk dialog, forstået som en dynamisk transformation af forståelse gennem interaktion. Dialogisk diskussion beskrives her som en åben og dybdegående udveksling af idéer og forståelser (Nystrand et al., 2003).

Denne form for kommunikation vil være udfordret i en naturvidenskabelig kontekst som bioanalytikeruddannelsens, hvor man arbejder med læringsmål, og hvor studerende skal forstå det rigtige svar på en naturvidenskabelig problemstilling. Men udfordringen tages der højde for i Nystrands (2003) beskrivelse af, at det ikke er er nødvendigt med dialogisk diskussion som eneste måde at kommunikere på. Der kan også være en værdi i at undervisningen rummer dialogiske "spells", som af Nystrand et al (2003) beskrives som "dialog et sted mellem åben diskussion og recitation", med engagerede studerende, der stiller spørgsmål og underviseren, der undlader at stille testspørgsmål. Både dialogiske spells og dialogisk diskussion kan i flg. Nystrand et al (2003) fremmes i et klasserum gennem at underviseren:

1. stiller autentiske spørgsmål og udfordrer eleverne til at formulere deres egen mening og forståelser.

2. optager studerendes forklaringer og forståelser i den videre samtale, uden at det går ud over den tematiske sammenhæng.

3. værdsætter det, eleverne siger og bruger det i den videre dialog (Nystrand m.fl., 2003).

Ofte sker der en forstyrrelse, idet kommunikationen er forstyrret af teknologi og medieret i et onlinerum. Denne form for forstyrrelse og dens konsekvenser for undervisningen berøres senere i artiklen.

\section{At være til stede i flere rum}


Levinsen, Ørngreen og Buhl (2013) beskriver de faktorer, som influerer på oprettelsen af en delt læringssituation i det, de kalder "det tredje undervisningsrum" ${ }^{1}$, dvs. de virtuelle rum, der etableres som et resultat af sammensmeltning af to fysiske rum. I nærværende case er de to fysiske rum undervisningslokalet på VIA og den studerendes onlinelokation. I det tredje undervisningsrum skal der i flg. Levinsen et al (2013) etableres en ny forståelse, da de kulturelle og tavse forståelser fra det traditionelle undervisningslokale ikke kan transmitteres direkte til det tredje undervisningsrum. Dette påvirker underviseren og de studerendes rolle, da de er nødt til at blive fortrolige med den splittede tilstedeværelse og måder at interagere simultant i fysiske rum og i det tredje, virtuelle undervisningsrum (Levinsen et al., 2013). Denne opfattelse er også at finde hos Wang et al. (2017), som også pointerer, at underviseren skal have tilstedeværelse (attention) både i det fysiske rum og i onlinerummet, hvilket er en udfordring. Det er vigtigt at underviseren vænner sig til teknologien, så den bliver transparent. Dog forholder Wang et al. (2017) sig ikke yderlig til det didaktiske i livestreaming (Wang m.fl., 2017).

Det er særligt centralt, at underviser og studerende oplever rum, der er opsat til at understøtte den synkrone dialog. Nortvig (2014) beskriver, at underviseren er $n ø \mathrm{dt}$ til at agere i en splittet tilstedeværelse i de to rum, det fysiske lokale og i onlinerummet. Kropsliggørelse af teknologien bliver derved vigtig for oplevelsen og for at kunne deltage frit, uden at opleve teknologien som en hindring. Dette suppleres af Ihdes (2002) tanker om at mennesket erfarer omverdenen gennem teknologi. Teknologien bør optimalt set reduceres i deltagernes opmærksomhed, som i stedet skal fokuseres på emnet i undervisningssituationen.

Ved VIA Bioanalytikeruddannelsen har et nethold på ca. 30 studerende face-to-face-undervisning 2-3 dage pr uge. Face-to-face undervisningen giver de studerende og underviserne basis for at kende hinanden og opbygge fælles sprog, symboler, humor, historie og omgangstone, hvilket støtter deres kommunikation i undervisningen som livestreames (Nortvig, Christiansen, Karlsen, Spante, \& Wicke, 2015).

\section{Teknologiens rolle for det didaktiske design}

Introduceres videostreaming til traditionel undervisning, kan det være en udfordring i sig selv, at et videosignal substituerer den situation, hvor studerende er til stede i undervisningslokalet (Ørngreen m.fl., 2013). Undervisningslokalet øges med et tredje undervisningsrum, og der introduceres skærmdeling med studerende. Hvis ikke hensynet til underviseres ønske om at kunne genanvende undervisningsforløb fra

\footnotetext{
${ }^{1}$ Det tredje undervisningsrum skal ikke forveksles med "det tredje læringsrum". Et begreb, som anvendes i professionsuddannelser om læringsrummet hvori teori og praksis mødes
} 
traditionel undervisning blev imødekommet, ville en modifikation eller en redefinition af det didaktiske design kunne tilpasse undervisningen til den teknologi, der var blevet introduceret, og dermed skabe en transformation af det didaktiske design, hvilket Karsten Gynther (2006) vil argumentere for sker. Dette kan også ses i forhold til at skabe god undervisning i en livestreamet kontekst, samt understøtte muligheden for dialog og interaktion, når der kombineres mellem tilstedeværelse og livestreamet deltagelse.

\section{Undersøgelsesdesign}

Artiklen baseres på data indsamlet via fokusgruppeinterviews (FGI) af alle uddannelsens 18 teori-undervisere, som deltog i grupper á 5-7 (se tabel 2). Der blev valgt fokusgruppeinterview med undervisere som metode, da denne form for interviews kan frembringe holdninger og erfaringer fra interviewdeltagere, idet de kan inspirere hinanden i samtalen, som er styret af interviewer (Kvale \& Brinkmann, 2009).

Fokusgruppeinterview nr. 2 og 3 have deltagere med som enten havde erfaring med et tidligere setup eller med hhv. en eller to undervisere, som endnu ikke havde prøvet det. Deres holdning til livestreamet undervisning vil være værdifuld ift. forventninger til setup'et og er derfor også inkluderet i undersøgelsen.

Tabel 2, Oversigt over fokusgruppeinterviews, undervisere opdeles i tre forskellige typer: A) uerfarne ift livestreamet undervisning, B) erfarne ifht. tidligere setup og C) erfarne med nyeste setup.

\begin{tabular}{|l|l|l|l|}
\hline $\begin{array}{l}\text { FGI } \\
\mathrm{nr}\end{array}$ & Deltagere & Deltagerprofil & FGI varighed \\
\hline 1 & 5 undervisere & 5 type B & 23 minutter \\
\hline 2 & 6 undervisere & 1 type A, 5 type B & 22 minutter \\
\hline 3 & 7 undervisere & 2 type A, 5 type B & 24 minutter \\
\hline 4 & 4 undervisere & 4 type C & 45 minutter \\
\hline
\end{tabular}

\section{Databehandling}

Databehandlingen blev lavet ud fra en deduktiv tilgang, idet de tre interviews (nr 1, 2 og 3) ikke var struktureret ud fra andre temaer end 'livestreaming af undervisning'. Formålet var at få indblik i undervisernes umiddelbare holdning til de emner, der fyldte mest i undervisernes oplevelse af livestreamet undervisning, således dette ville blive afdækket. Analyse af interview nr. 1, 2 og 3 udføres jf. Kvale og Brinkmanns (2009) model med faserne: overblik, tematisering, meningskondensering, kategorisering, analyse og fortolkning (Kvale \& Brinkmann, 2009).

I analysen af FGI nr. 1, 2 og 3 identificeres fire centrale temaer hørende under den overordnede problemstilling om de didaktiske og teknologiske udfordringer, som underviserne oplever i livestreamet undervisning, samt den indflydelse undervisningsformen har på dialog og interaktion. Der blev 
desuden etableret en kategori om undervisernes ønsker og mulige potentialer relateret til undervisningsformen.

Gennem analyserne udvikledes 4 kategorier, som efterfølgende er omformuleret til spørgsmål, som anvendes i fokusgruppeinterview 4:

\section{1) Didaktik}

a) Hvilke didaktiske designs vil underviserne gerne kunne anvende i deres undervisning?

\section{2) Interaktion og kommunikation}

a) Hvordan er underviserens fornemmelse af studerendes respons på det der sker i undervisningen?

b) Hvordan opleves kommunikationen mellem undervisere og studerende?

\section{3) Teknologien}

a) Hvad er teknologiens betydning for underviseres oplevelse af undervisning?

\section{4) Potentialer}

a) Kan teknologien/det nyindrettede rum medføre en positiv didaktisk transformation?

\section{Fokusgruppeinterview med erfarne undervisere}

Fokusgruppeinterview 4 var med fire undervisere, som alle var bekendte med teknologien, undervisningstilrettelæggelsen og forudsætningerne for livestreamet undervisning i det nyindrettede lokale. Dette interview var semistruktureret med udgangspunkt i de 4 førnævnte kategorier. Underviserne blev derfor interviewet om deres oplevelse af det teknologiske setup, om deres oplevelse af interaktion med online studerende og om potentialer i forhold til lokalets indretning. Data fra dette interview blev analyseret indenfor de fire kategorier, som tidligere var identificeret.

\section{Analyse \& diskussion}

I det følgende danner de 4 kategorier grundlaget for en diskussion af undervisernes udfordringer, oplevelse og ønsker i forhold til livestreamet undervisning.

\section{Didaktik}

\section{Hvilke didaktiske designs vil underviserne gerne kunne anvende $i$ deres undervisning?}

Det er et centralt ønske fra underviserne, at de kan overføre deres praksis fra den traditionelle IRE-strukturerede tilstedeværelsesundervisning jf (Nystrand, 1997) og dialogorienterede undervisning til livestreamet undervisning. Dette begrundes både i de organisatoriske rammer udstukket fra uddannelsens ledelse samt undervisernes oplevelse af, at de i tilstedeværelsesundervisningen bedriver god undervisning. 
I undervisernes forståelse af god undervisning er ligeledes de studerendes aktive deltagelse vigtig ift. at bidrage til fælles vidensopbygning og faglig forståelse. Underviserne ytrer ønske om at kunne aktivere og interagere med de studerende på traditionel klasserumsvis bl.a. ved at studerende kommer til tavlen, og at de deler skitser, tegninger og andre visuelle beskrivelser i undervisningen. Tilsvarende vil mange af underviserne gerne via tavle kunne skitsere processer, figurer og grafer i hånden, idet det $\mathrm{i}$ undervisernes forståelse er en god måde at formidle på.

\section{"Teknologien skal være sådan, atjeg kan gå ind og gøre det samme, uanset om det er en ordinær klasse eller det er en netklasse." [Underviser M] \\ "Det vil være fedt, hvis man kunne skrive på en tavle så man ville være fri for den (Epson-pen)" \\ [Underviser B]}

Underviserne vil gerne selv kunne vælge, hvorvidt de vil anvende tavle/whiteboard, egen PC eller lokalets PC i deres undervisning, hvorfor rummet er indrettet, så det nemt kan tilpasses den enkelte undervisers $\emptyset$ nsker og behov. De erfarne undervisere pointerer, at indretningen af lokalet med en tavle og et kamera, som filmer tavlen i høj opløsning (jf. fig 4), har vist sig som en potentiel og vigtig forbedring, i forhold til den tidligere mobile løsning, hvor der kun var mulighed for at anvende interaktiv tavle².

Som en følge af undervisernes ønske om at kunne bruge den didaktik, de kender fra øvrig undervisning, vil der ikke automatisk finde en konkret redidaktisering sted. Der kan argumenteres for en vis form for tilpasning $\mathrm{i}$ forhold til inddragelse af teknologien og tilblivelsen af det tredje undervisningsrum. Valget at bevare kendt undervisningsform har den konsekvens, at der udelukkende sker en udvidelse i forhold til den eksisterende undervisning. Udvidelsen er med det tredje undervisningsrum - med mulighed for skærmdeling til alle deltagende studerendes egen PC, og med adgang til en chat parallelt i undervisningen. Men ingen af disse påvirker didaktikken umiddelbart mod "god undervisning" som er bedre end IRE, som Nystrand beskriver det (Nystrand m.fl., 2003).

\footnotetext{
2 Enkelte undervisere brugte håndtegningsfunktionen i Word og Epsonprojektorens musefunktion i en tilhørende pen eller projektorens elektroniske whiteboardfunktion. Men begge var afhængig af tidsrøvende kalibrering af projektor og pen.
} 
Underviserne beskriver det som en forudsætning, at alt foregår synkront og ikke asynkront, hvilket teknologi generelt ellers kan give mulighed for, fx video-introduktioner til nyt fagligt stof som i flipped learning (Hachmann \& Holmboe, 2014) eller ved at optage de livestreamede undervisningssessioner mhp at give de studerende mulighed for at gense undervisningen (Amanjot, Aviva, Darren, Jodi, \& Adrian, 2017; B. Meyer, Jensen, Schleicher, \& Zoë, 2017). Denne form for anvendelse af et livestreamet setup, hvor det optages mhp. at studerende, der ikke deltager i undervisningen, kan se og høre underviseroplæg og diskussion efterfølgende har i flg. Meyer et al. en stor værdi for disse asynkront deltagende studerende (B. Meyer, Jensen, Schleicher, \& Zoë, 2017).

Idet den tidsmæssige fleksibilitet ikke vælges systematisk som en mulighed for didaktisk modifikation, er det udelukkende sted-fleksibilitet, teknologien tilføjer til undervisningen. Undervisernes ønske om at understøtte en bevægelse mod studerendes aktive deltagelse modsiges til en vis grad af deres beskrivelse af ønsket om at formidle ved tavlen. Underviserne kunne øge de studerendes aktive deltagelse gennem brug af flipped design i undervisningen (Hachmann \& Holmboe, 2014) uanset om det livestreames eller ikke.

En anden måde, undervisere kan aktivere de studerende på, er ved at udforme opgaver, der fordrer de studerendes dialog, evt. i

onlinegrupperum. Tildeles opgaver til studiegrupper, hvor man som gruppe bliver kollektivt ansvarlig for en del af det, der skal præsenteres for hele klassen vil det desuden fremme studerendes aktivitet (Danmarks Evalueringsinstitut, 2016)

\section{Interaktion og kommunikation}

Hvordan er underviserens fornemmelse af studerendes respons på det der sker i undervisningen?

Det tredje undervisningsrum som Levinsen (2013) beskriver, er formodentlig ikke fuldt etableret i undervisernes bevidsthed, eftersom underviserne beskriver, at de til tider oplever de studerende som passive, når de ikke kan ses af underviseren. Dette kan være begrundet i oplevelser med studerende, som ikke ses via videostream, kan finde på at "forsvinde" fra det tredje undervisningsrum.

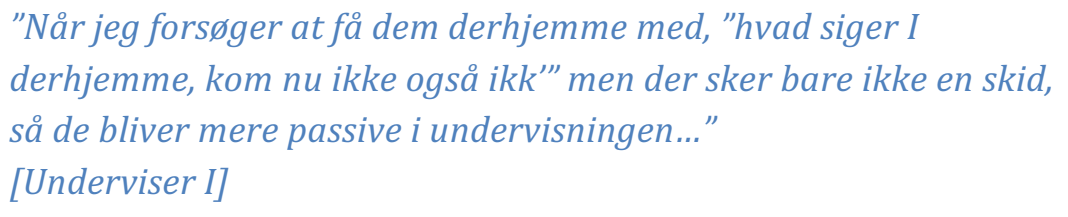

Underviseren her forsøger aktivt at integrere studerende hjemmefra, men da det for underviseren ikke er muligt at se, om den studerende er gået fra computeren eller om manglende respons kan være af teknisk karakter, kan 
underviseren forledes til at tro, at den studerende ikke er "til stede". Hvis studerende derimod deltager aktivt hjemmefra og vises i videostream, er det undervisernes oplevelse, at interaktionen ikke påvirkes af kombinationen af tilstedeværelse eller online.

\section{"Jeg kan jo læse rigtig meget ud af de studerende når jeg kan se dem, men hvis ikke jeg kan se dem så kan jeg jo ikke læse dem. Og nogen gange kan jeg også være enormt meget i tvivl om hvor mange sidder der egentlig faktisk nede bagved? (på skærmen)" [Underviser L]}

"Jeg er enormt glad for at kunne komme til at se dem derude, at få ansigter på dem derude. Det var mit største ønske, at kunne se dem derude."

[Underviser J]

Underviserne husker ikke altid tilstedeværelsen af studerende, som deltager online, når deres tilstedeværelse ikke er synlig for underviseren via livestream fra deres webcamera. Teknologien og det tekniske setup bliver en begrænsende faktor i den sammenhæng, idet det kun er de fem online studerende, der senest har sagt noget, som kan ses. Hvis 20 studerende sidder hjemme, vil der altså være 15 studerende, der ikke er umiddelbart synlig for underviseren. Disse studerende skal underviseren bruge ekstra mental energi på at huske aktivt at inddrage i sin interaktion og kommunikation med gruppen af studerende.

Interaktion er vigtig for underviseren for at kunne tilpasse dialogen på baggrund af studerendes reaktioner. Der kan argumenteres for at interaktion bliver mere vigtig for at underviserne bevarer følingen med studerende, der deltager via livestreaming. Denne fokus på interaktion og kommunikation ud fra studerendes reaktioner understøttes både af Jahnkes (2016) beskrivelse af "CrossActionSpace", hvor kommunikationen i undervisningen skal være lærende-centreret og Nystrands (1997) beskrivelse af dialogens betydning for studerendes udbytte. Ifølge Rehn et al. (2017) kan der være en pointe i at underviserne ændrer deres pædagogiske tilgang fra at tænke traditionel undervisning til at bruge mere studenter-centrerede tilgange for at skabe interaktion og det Rehn et al (2017) kalder "connected classrooms".

Reaktionerne, som underviseren aflæser hos de studerende, kan såvel som studerendes ordvalg også være de kropslige reaktioner. Disse er afhængige af, i hvor høj grad teknologien ifølge Nortvig (2014) er "kropsliggjort". Så længe teknologien resulterer i "disembodiment", er der risiko for at undervisere og studerende kommer til at fokusere på teknologien i stedet for indholdet i kommunikationen. Teknologien kan potentielt integreres naturligt i underviserens tilrettelæggelse og ageren i klasserummet (Wang m.fl., 2017), men det kan på den anden side være svært helt at undgå 
risikoen for, at teknologien påvirker dialogen og derved forstyrrer den "intenderede kommunikation" (Mathiasen, 2011).

Hvordan opleves kommunikationen mellem undervisere og studerende? Dynamikken og dialogen er påvirket i en medieret undervisningskontekst i en sådan grad, at man som underviser skal være bevidst om en længere "pinlighedspause", som opstår efter et spørgsmål er stillet fra underviser til studerende.

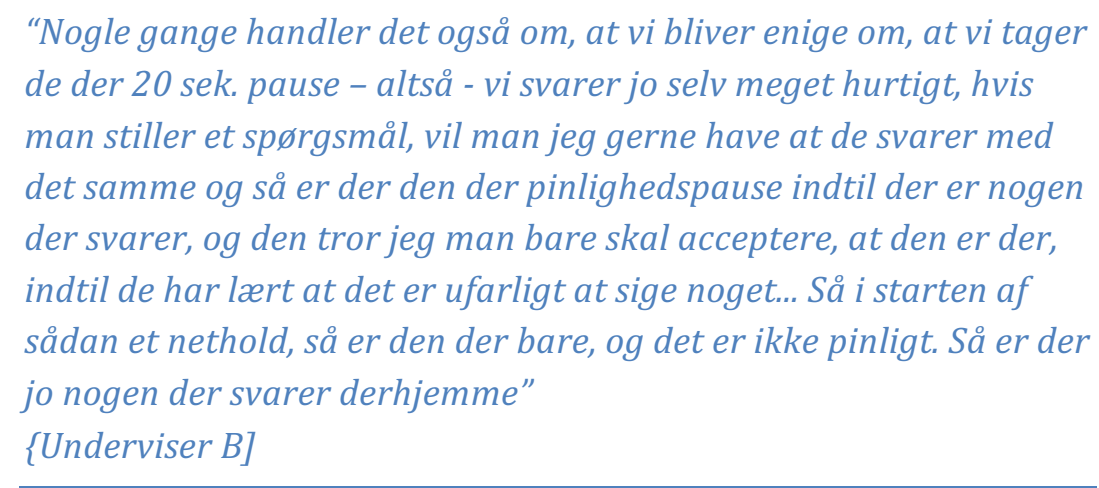

Underviserne beskriver det som, at det koster "mentale afbræk" at samtalen bliver forsinket tidsmæssigt af, at de studerende: 1) Skal beslutte sig for at turde svare uden at kunne se, om andre er ved at tage sig sammen til at svar. Herefter skal de 2) have fat i musen og 3) unmute deres mikrofon, inden de kan 4) melde ind i onlinerummet med deres bidrag.

Nortvig (2014) mener, at tidsforsinkelsen kan blive en naturlig del af dialogen, efterhånden som den spredte topologi ikke føles begrænsende, og der er sket "embodiment". Dette kan sidestilles med underviserens forståelse af, at man skal acceptere pinlighedspausen indtil de studerende har vænnet sig til at det er ufarligt at sige noget. Det kan være svært at få denne embodiment til at ske fuldstændigt, idet der er traditionel face-toface undervisning to til tre hverdage om ugen, hvorved den største del af undervisningen sker i traditionel kontekst og den medierede kun er én eller to dage ugentligt. De studerende har altså to forskellige typer studiehverdage, hvor den ene typer indeholder et medieret, tredje undervisningsrum (Levinsen m.fl., 2013). Det skaber derfor et behov for øget opmærksomhed omkring den dialogform og interaktion, der er i den medierede kontekst, da den vil optræde anderledes end dialogformen og interaktionsmulighederne i traditionel undervisning (Weitze \& Ørngreen, 2014).

Den forsinkelse der opstår i samtalen må uundgåeligt påvirke den dialogiske proces i klasserummet, som Nystrand et al (Nystrand m.fl., 2003) beskriver den, og som Dysthe underbygger i sin beskrivelse af hvordan man understøtter etableringen af "det flerstemmige klasserum" (Dysthe, 1997). Hvis underviseren skal optage studerendes input $\mathrm{i}$ 
efterfølgende dialog og lade det skinne igennem, at studerendes mening og forståelse er central for den gode undervisning, er man udfordret af en tidsmæssig forsinkelse. Men den er næppe alene med til at hæmme etableringen af flerstemmighed. Det kan også være undervisernes grundlæggende naturvidenskabelige læringstradition, som kan spænde ben for etableringen af en ægte dialog i Bakthins forståelse, som Nystrand (2003) refererer til (Nystrand m.fl., 2003). Underviserne er selv uddannet i en naturvidenskabelig tradition med en underviser, der "har sandheden", og hvis fornemste opgave er at fortælle de studerende denne sandhed gennem monolog. De kan let komme til at overføre denne erfaring til egen undervisning, hvor monologen kan få en form, i hvilken studerende blot udfylder elementer i en undervisers monolog - en samtale styret af underviser og med et bestemt mål.

Kommunikationen mellem undervisere og studerende påvirkes ikke uventet af den medierede samtaleform og den har dermed også indflydelse på interaktionen mellem deltagerne. Der er dog mulighed for, at man ved at følge nogle få, simple spilleregler (visuel markering), nemmere kan fokusere på det, der kommunikeres om. Integreres fælles, simple spilleregler for $\mathrm{fx}$ visuel markering i undervisningsrummet, vil det nærme sig det, Nortvig kalder kropsliggørelse af teknologien (Nortvig, 2014). Samtidigt vil det ifølge Weitze og Ørngreen (2014) kræve ekstra opmærksomhed fra undervisers side at sikre, at alle studerende uafhængigt af topos føler sig som ligeværdige deltagere. Synlighed kan være et eksempel på styrkelsen af kommunikationen mellem underviser og studerende. At onlinestuderende har tændt deres webcamera og dermed kan ses i lokalet er vigtigt, da det har positiv indflydelse på interaktionen mellem underviser og studerende.

Det er undervisernes ønske, at de studerende, der deltager ved fremmøde, ikke får dårligere undervisning, og f.eks. føler at kommunikationen med underviser er begrænset, fordi undervisningen streames. Dette kræver, at underviserne er i stand til at manøvrere som i det fysiske rum med samme grad af mental tilstedeværelse i det tredje undervisningsrum, så de skal være til stede i to rum parallelt. Derfor må embodiment og integration af det tredje undervisningsrum være et mål for, at dialogen i livestreamingen ikke er så forstyrret, at der ikke kan bedrives "god undervisning" (H. Meyer, 2005).

\section{Chatrummets anvendelse}

Lyden som den vigtigste modalitet er den, underviserne ønsker at anvende i stedet for fx chat, når onlinestuderende vil til orde i undervisningen.

"Mange gange får jeg at vide af en i klassen, at der er en på
chatten, det opdager jeg jo ikke, hvis ikke jeg står henne ved på 
computer eller..."
[Underviser B]

"Der er fair nok at sige: Jamen jeg reagerer ikke på chatten, de må tænde kameraet og spørge."

[Underviser J]

Chatten ses kun som et talerør mellem studerende og underviser i den type undervisning, hvor de studerende sidder og arbejder med konkrete opgaver og underviserne vejleder. Her kan underviserne bruge den kommunikationsform, som ikke afbryder dem i f.eks. at forklare noget for en studerende, og samtidigt vil en "kø" $i$ chatten også vise de øvrige studerende, hvor mange der er i "kø" til at blive vejledt.

Ofte opleves at online-studerende enten blot bryder ind med risiko for at bryde talerækken, eller også holder de sig tilbage, fordi de ikke er sikre på, om de bryder ind foran andre. Begge situationer er ikke ønskværdige, men afspejler den nuværende situationen, idet videosignalet ikke nødvendigvis viser, om nogle studerende i lokalet har markeret, eller om en anden onlinestuderende gerne vil sige noget.

Generelt set er der tale om flere forskellige måder på hvordan kommunikationen med online studerende foregår. På den ene side er der dialogisk monolog ved forelæsnings-seancen eller ved fælles gennemgang af opgavesvar, hvor online studerende kan afbryde eller 'række hånden op', og på den anden side en skriftlig dialog-form med 'chat-kø', når der arbejdes med opgaver eller vejledes, som ikke virker forstyrrende. Ingen undervisere nævner den meningsudvekslende dialog, hvor

"...truth is not born to be found inside the head of an individual person, it is born between people collectively searching for thruth, in the proces of their dialogic interaction"

(Bakhtin, 1984 i (Nystrand, 1997).

Måske dette fravær af reel meningsudvekslende dialog kan forklares med den fagdidaktiske tradition for monologisk undervisning som nævnt tidligere, men fagdidaktik kan ikke alene anvendes som argument for bevidst fravær af dialogisk kommunikation. Det skal nok også begrundes i onlinerummets tidsmæssige benspænd for kommunikationen og i visse tilfælde også i begrænsningen af fornemmelse for hinanden i det tredje undervisningsrum (Levinsen m.fl., 2013; Nortvig m.fl., 2015)

Det er undervisernes oplevelse, at chatten kan hjælpe i nogle situationer og tilføje en ekstra modalitet, hvilket iflg Kress og Leeuwen (2001) vil berige kommunikationen. Men det vil altid være en balancegang for underviserne ift. hvor rig kommunikationen skal være og hvor mange 
kommunikationsveje, de skal være klar på at inddrage i deres kommunikation og interaktion med studerende. Vælger undervisere få modaliteter i kommunikationen ( $\mathrm{fx}$ kun lyd), risikerer de at miste finesser og detaljer i meningsudvekslingen med risiko for misforståelser. Alternativet er, at der skal jongleres med mange modaliteter båret af forskellig teknologi og evt. også inddrages studerende som ekstradeltagere/mediatorer i kommunikationen, hvis de får til opgave at holde øje med chat fra studerende hjemmefra eller at styre en talerække.

\section{Teknologi}

\section{Hvad er teknologiens betydning for underviseres oplevelse af undervisning?}

Underviserne frustreres, når de har oplevelsen af, at teknologien begrænser deres undervisning, og de giver udtryk for at undervisning på netholdet er stressende.

"Jeg har altid et kæmpe højt stressniveau, når jeg har de timer her." [Underviser B]

Livestreaming af undervisningen kræver af de online studerende, at de kan håndtere deres egen PCs lyd- og videoindstillinger, og at de samtidigt kan håndtere softwaren. En konsekvens af at gøre de studerende afhængige af teknologi for at deltage i undervisning har været, at de studerende har oparbejdet it-kompetencer. Studerende bliver oplært i det tekniske, hvilket sker indledningsvist i en enkelt lektion. Herfra bliver de mest kompetente studerende, som er hurtigst til at forstå teknologien, centrale for de øvrige studerende.

Undervisere oplever, at de studerende hjælper hinanden, og studerende har også givet teknisk assistance til undervisere med idéer fra det, de ser andre undervisere gøre. Undervisere beskriver, at de ikke selv kan hjælpe studerende, fordi brugerfladen på den studerendes PC er så forskellig fra underviserens brugerflade. Derfor er det undervisernes holdning, at de studerende, der bliver hjemme og deltager online, skal kunne klare sig selv.

\section{Tavlen som en teknologi}

Mange undervisere bruger tavlen i lokalet i deres undervisning, fx hvis de for at besvare et spørgsmål, kort skal forklare en problemstilling, en beregning eller skitsere biologiske strukturer (se fig. 5). Som en underviser udtrykker det.

\section{"[Det er] fedt at kunne tegne på tavlen." [Underviser K]}

Det kræver som det eneste af underviserne, at de sikrer sig, at kameraet peger på tavlen og ikke viser hele lokalet med studerende. Underviserne 
overfører dermed i høj grad deres vante ageren fra øvrig undervisning til det livestreamede undervisningsrum.

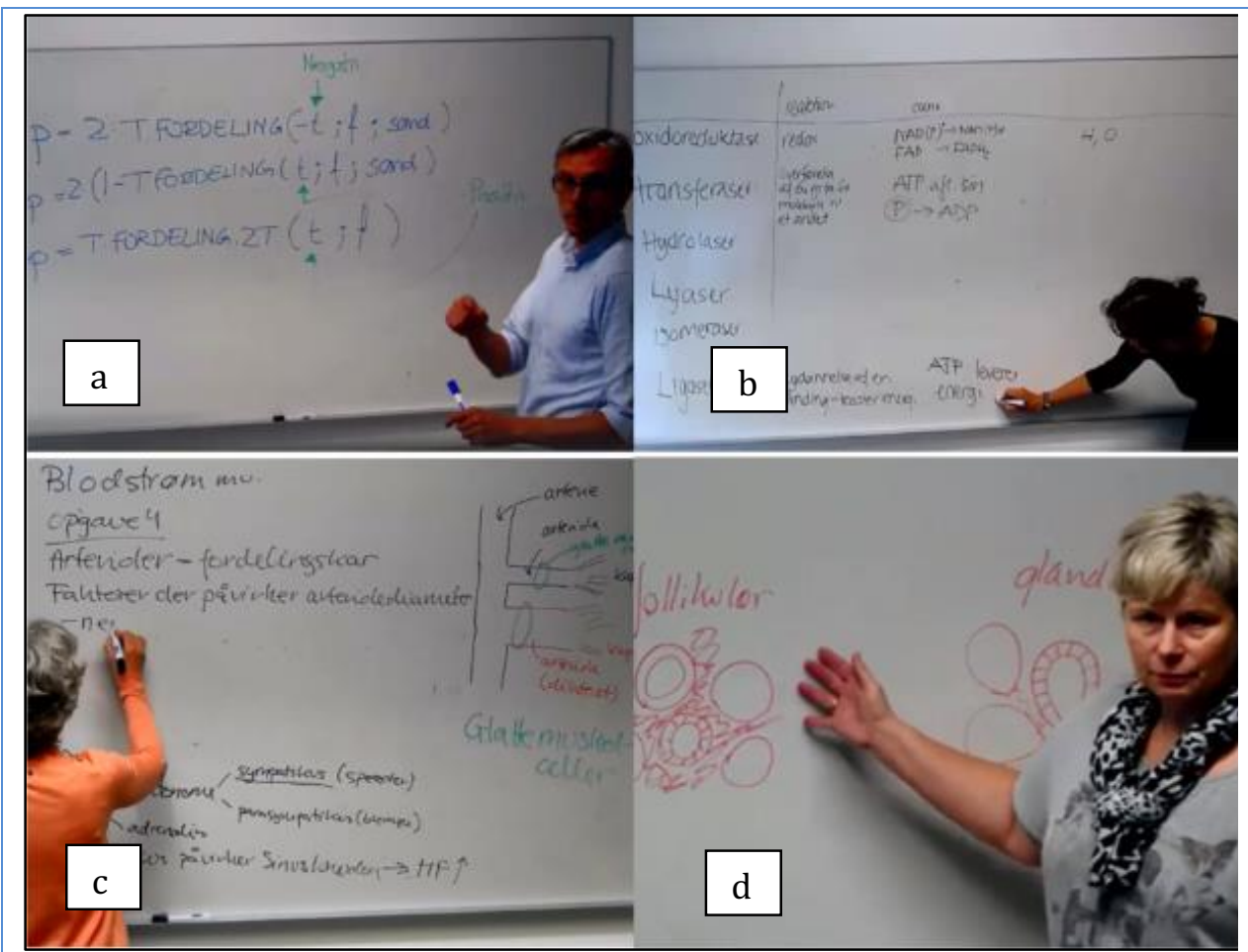

Figur 4 Fire forskellige undervisere, der alle bruger whiteboard som en teknologisk støtte $i$ dialogen og interaktionen med de studerende. a) Én underviser forklarer statistikberegninger, mens holdet arbejder med opgaver, $b$ ) en underviser præsenterer en oversigt over enzymer på tabelform, c) en underviser gennemgår besvarelsen af en opgave og d) en underviser forklarer fagudtryk, som der arbejdes med i en videnskabelig artikel.

Der er undervisere, som har oplevet nedbrud af teknologien. Disse nedbrud har alle haft en karakter, som sandsynligvis er uundgåelige, men ikke desto mindre, skaber det forstyrrelser i undervisningen, da underviserne mister fokus og undervisningstid. En konsekvens heraf kan være, at flere undervisere vælger udelukkende at bruge whiteboard som teknologi til at understøtte formidling og ikke kombinerer det med skærmdeling, hvilket ellers er mest normalt i den øvrige undervisning.

\section{Lydkvalitetens konsekvenser}

Transmissionen af lyd er en vigtig faktor for undervisernes oplevelse af kvalitet i den livestreamede undervisning. I den tidlige mobile løsning var der ofte lydsignal af dårlig kvalitet fra undervisningslokalet til de studerende pga. begrænsninger i muligheder for mikrofonernes placering. Disse begrænsninger resulterede $i$, at undervisere ofte skulle gentage, hvad der blev sagt $i$ fælles diskussioner. I det nuværende setup er lydsignalet i livestreamet meget følsomt. Den høje følsomhed resulterer i, at 
studerende hjemme sagtens kan høre, hvad fremmødte studerende siger, men de kan også sagtens høre, når de fremmødte blot hvisker med sidemanden, rasler med papir, eller udefra forstyrrende lyde.

At underviserne finder det nemt at undervise i det nye livestreamede setup kan begrundes i både en forbedret lydkvalitet og at det er nemt for underviserne, at anvende tavlen som en teknologi til at fastholde det talte ord. Denne teknologi er vel at mærke ikke med til at øge kompleksiteten, hvilket både underviser-PC-skærmdeling og studerende-fremlæggelse ville gøre. Brug af tavlen løfter ikke det didaktiske design fra den type undervisning, man kender fra klasserummet, men fastholder måske i højere grad en gammel-kendt undervisningstilrettelæggelse med brug af whiteboard/tavle. Dette set overfor at engagere studerende via de digitale kommunikationskanaler, de har i online grupperum, og ved at lade studerende præsentere via skærmdelen af deres PC ind i onlineklasserummet.

\section{Potentialer i det tredje undervisningsrum}

Adspurgt om underviserne kan se nogle uudnyttede potentialer i det nyindrettede lokale, er det mest dominerende svar, at de gerne vil udvikle undervisningen på netholdet/netdage, men at de ikke er klar til at påbegynde udviklingen før de føler, at de mestrer teknologien og teknologien ikke svigter. Nogle undervisere nævner, at de ser muligheder i forbindelse med at ligestille online-studerende med de fremmødte studerende ved hjælp af teknologien. En underviser nævner, at han ser potentiale for, at de studerende făr en større it-teknologisk pallette og kompetencer inden for brugen af it generelt til at understøtte deres læreproces.

Idet der i livestreaming etableres et tredje undervisningsrum/et onlinerum, vil der desuden være et potentiale for, at man nu teoretisk set kan invitere flere online-deltagere med i undervisningen end dem, der umiddelbart er tilknyttet de enkelte hold af studerende. For eksempel foreslås det at inddrage kliniske undervisere eller studerende i praktik i undervisningen på en netdag, og dermed invitere til mere samarbejde og interaktion i en tværprofessionel professionskontekst.

"Man kan jo også lave noget der er mere samarbejdsvenligt med den kliniske undervisning. - de kan præsentere case og kan logge på fra praktikken."

[Underviser M]

"Eldre studerende kunne gå ind i vejledning via denne løsning." [Underviser T] 
De positive konsekvenser af et sådant udvidet samarbejde vil være en tættere praksistilknytning til teoriundervisning, og det kan også skabe mulighed for et bredere perspektiv i de dialoger, der kan forekomme i undervisningen samt mulighed for at inddrage studerende fra andre semestre eller undervisere og studerende fra andre uddannelser $\mathrm{i}$ undervisningen.

Et udvidet samarbejde kan dog være udfordret af deltagernes opfattelse af, hvilken rolle de spiller. Der bliver en øget kompleksitet og den enkelte deltagers oplevelse kan blive påvirket af denne kompleksitet med flere roller end de to kendte: en underviser og nogle studerende (Dalsgaard, 2017).

Inviteres yderligere brugergrupper ind, vil der desuden være risiko for organisatoriske interessekonflikter mellem grunduddannelse og efter/videreuddannelse. Der kan desuden potentielt set være konsekvenser for interaktionen i onlinerummet, da den er påvirket af det fællesskab og den fælles kultur, som studerende og underviser opbygger på de dage, hvor der er undervisning på campus. Opbygningen af den type fælles kultur ville "gæsterne" i så fald ikke være en del af.

\section{Konklusion}

Hensigten med denne artikel har været at beskrive, hvordan undervisere oplever udfordringer ved livestreamet undervisning, hvilket er gjort gennem diskussion af de didaktiske og teknologiske udfordringer, undervisere er stødt på. Desuden er det diskuteret, hvordan kommunikation og interaktion i denne form for undervisning påvirkes og om nye muligheder opstår som en følge af tilførte teknologiske elementer til undervisningsrummet.

Undersøgelsen baseredes på fokusgruppeinterview, hvor enkelte undervisere $i$ to af interviewene ikke har erfaring med livestreamet undervisning. Disse undervisere deltog i interviewene med deres ønsker til livestreamet undervisning og bidrog med data som har lige så stor værdi, som de undervisere, der har prøvet det.

Der har været fokus på undervisernes benspænd i form af forandrede rammer for deres undervisning via introduktion af et livestreamingkoncept. De forandrede rammer har resulteret $i$, at underviserne er blevet opmærksomme på, hvilke elementer, de vurderer som vigtige for at kunne praktisere "god undervisning", nemlig fornemmelse af de studerendes tilstedeværelse og mulighed for at kunne genbruge didaktiske designs fra øvrig undervisningspraksis. 
En videre bearbejdning af Hilbert Meyers (2005) ti punkter (tidligere præsenteret) sat ind i en professionsdidaktisk ramme som punkter for "god undervisning" ville kunne være således:

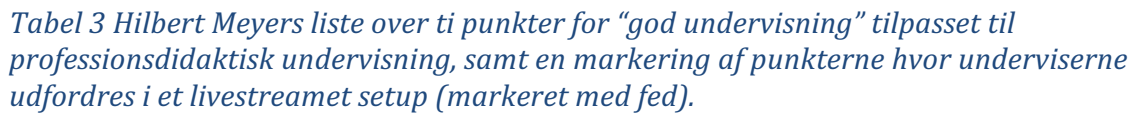

\begin{tabular}{|c|c|c|}
\hline 1 & $\begin{array}{l}\text { Rød tråd og } \\
\text { struktur. }\end{array}$ & $\begin{array}{l}\text { Studerende skal forstå sammenhængen mellem } \\
\text { det aktuelle fag, øvrige fag og professionel } \\
\text { praksis og studerende skal kende til } \\
\text { undervisningsforløbet struktur }\end{array}$ \\
\hline 2 & $\begin{array}{l}\text { Brug tiden på } \\
\text { læring }\end{array}$ & $\begin{array}{l}\text { Underviser skal i lektioner fokusere på } \\
\text { dialogen med studerende; elementer der kan } \\
\text { afvikles elektronisk inden undervisningen, } \\
\text { skal være på plads inden }\end{array}$ \\
\hline 3 & $\begin{array}{l}\text { Giv eleverne lyst til } \\
\text { at deltage }\end{array}$ & $\begin{array}{l}\text { Studerende skal motiveres gennem indsigt i fag } \\
\text { og emners relevans og forståelse af teori i } \\
\text { relation til professionsudøvelse samt gennem } \\
\text { ligeværdig dialog }\end{array}$ \\
\hline 4 & $\begin{array}{l}\text { Aktiver det, } \\
\text { eleverne ved i } \\
\text { forvejen }\end{array}$ & $\begin{array}{l}\text { Undervisningens indhold skal baseres på kendt } \\
\text { tidligere pensum eller på studerendes } \\
\text { livsverden }\end{array}$ \\
\hline 5 & $\begin{array}{l}\text { Sæt ord på, hvad } \\
\text { eleverne skal lære } \\
\text { og hvorfor }\end{array}$ & $\begin{array}{l}\text { Læringsmålene for det aktuelle fag beskrives og } \\
\text { uddybes for de studerende }\end{array}$ \\
\hline 6 & Varier metoderne & $\begin{array}{l}\text { Tilrettelæggelse af studieaktiviteter i } \\
\text { lektionerne varieres }\end{array}$ \\
\hline 7 & $\begin{array}{l}\text { Tag individuelle } \\
\text { hensyn }\end{array}$ & $\begin{array}{l}\text { Tilpas kommunikationen til den enkelte } \\
\text { studerende }\end{array}$ \\
\hline 8 & $\begin{array}{l}\text { Træn - igen og igen } \\
\text { og målrettet }\end{array}$ & $\begin{array}{l}\text { Gentag indholdselementer, der er centrale for } \\
\text { professionen og anerkend, at studerende forstår } \\
\text { i forskellige tempi }\end{array}$ \\
\hline 9 & Fysiske rammer & $\begin{array}{l}\text { Tilpas undervisningsaktiviteten til det } \\
\text { lokale, der skal undervises i }\end{array}$ \\
\hline
\end{tabular}




\begin{tabular}{|l|l|l|}
\hline 10 & $\begin{array}{l}\text { Sig, hvad du } \\
\text { forventer }\end{array}$ & $\begin{array}{l}\text { Vis interesse for, at de studerende når } \\
\text { læringsmålene }\end{array}$ \\
\hline
\end{tabular}

For punkterne på denne liste gælder der særlige hensyn ved livestreamet undervisning. Her udfordres underviserne særligt ved punkterne 2, 6, 7 og 9, som har det til fælles, at de er påvirket af interaktionen mellem underviser og studerende.

Et lokale, som er blevet specielt indrettet til livestreamet undervisning, afhjælper en del af undervisernes udfordringer:

1) De kan se et givent antal af de online studerende af gangen

2) Der er et almindeligt whiteboard til rådighed og

3) Kvaliteten af lydtransmission ind og ud af lokalet er høj.

Alle disse tre elementer er med til at skabe muligheder for en bedre dialog med og mellem studerende (pkt 2 og 7) og give underviserne mulighed for at praktisere de didaktiske tiltag, de vurderer bedst for den enkelte lektion.

Tilbage er stadig:

1) At ikke alle onlinestuderende bliver vist via live webcam på LCDskærmen i lokalet, og at onlinestuderende ikke kan se om andre studerende ønsker at bidrage til en debat eller at stille et spørgsmål til underviser.

2) Problematikken med at der er så god lydtransmission, at det til tider forstyrrer, hvis der ikke er ro i lokalet og kun én taler ad gangen. Disse udfordringer kan man imødekomme ved at indarbejde regler for markering i en talerække og ved at studerende i lokalet lærer at være stille.

3) Dialogen er påvirket af forsinkelse. Denne forsinkelse kan man ikke umiddelbart eliminere, men man kan vænne sig til den, fx som Nortvig ville kalde "embodiment" af teknologien - at den bliver en sædvane, man ikke længere lægger mærke til i det daglige, hvorved indholdet i dialogen bliver det primære i fokus.

4) Anvendelse af flere kommunikationsmodaliteter. Underviserne ønsker ikke at skulle inddrage mere teknologi i deres kommunikation i dialogbaseret undervisning, kun når der arbejdes individuelt med studieaktiviteter. En studerende kunne assistere i dialogbaseret undervisning, om end dette kan påvirke den konkrete studerendes deltagelse negativt ved at skulle agere i flere roller som både moderator og som studerende.

Fra et teknologisk perspektiv anses Skype for Business som et stabilt software, som underviserne har erfaring med og som umiddelbart er stabilt. Underviserne har til gengæld erfaring med at netforbindelse, 
hardware eller brugerne af softwaret kan svigte. Det er undervisernes erfaring, at det er vigtigt, at studerende selv kan håndtere det tekniske hjemmefra, og opfyldes dette, opøver de studerende teknologiske kompetencer, og mange af de velkendte didaktiske metoder kan lade sig gøre i det livestreamede undervisningsrum.

En indretning af et dedikeret lokale med avanceret teknologi "under bordet" har vist sig at kunne svigte, hvorfor underviserne kan opleve nedbrud når der livestreames. Så længe der er teknologi inkluderet i undervisning, er der risiko for nedbrud, men man kan reducere risikoen for nedbrud ved at reducere antallet af teknologiske elementer, som undervisere skal håndtere.

\section{Referencer}

Amanjot, S., Aviva, F., Darren, L., Jodi, J., \& Adrian, G. (2017). Adding Live-

Streaming to Recorded Lectures in a Non-Distributed Pre-Clerkship

Medical Education Model. Studies in Health Technology and

Informatics, 292-297.

Buhl, M. (2015). Augmented reality som wearable. Læring Og Medier, 8(14).

Dalsgaard, C. (2017). Åbenhed i online uddannelser. I Netværk for Netbaserede Uddannelser (s. Keynote). Copenhagen.

Danmarks Evalueringsinstitut. (2016). Styrk de studerendes udbytte: inspiration til at arbejde med de studerendes studieintensitet. Kbh.: Danmarks Evalueringsinstitut.

Dysthe, O. (1997). Det flerstemmige klasserum skrivning og samtale for at lære. Forlaget Klim.

Gynther, K. (2006). Blended learning : it og læring i et teoretisk og praktisk perspektiv. Unge Pædagoger.

Hachmann, R., \& Holmboe, P. (2014). Flipped learning - mere end bare video (2. udgave,). Kbh: Nyt Teknisk Forlag.

Jahnke, I. (2016). Digital Didactical Designs - Teaching and Learning in CrossActionSpaces (1st udg.). Routledge. 
Jelsbak, V. A., Buus, L., Thorsen, J., Bendsen, T., \& Ørngreen, R. (2017).

Students' Experiences with Live Video-Streamed Teaching Classes. I

16th European Conference on e-Learning-ECEL 2017. Academic

Conferences and Publishing International.

Klibanov, O. M., Dolder, C., Anderson, K., Kehr, H. A., \& Woods, J. A. (2018).

Impact of distance education via interactive videoconferencing on students' course performance and satisfaction. Advances in Physiology Education, 42(1), 21-25.

Kress, G., \& Leeuwen, T. (2001). Multimodal and Media of Contemporary Communication. London Arnold.

Kvale, S., \& Brinkmann, S. (2009). Interview: det kvalitative forskningsinterview som håndværk. København: Hans Reitzels Forlag.

Landbo, A. S., Hedegaard, K. M., Nielsen, C., \& Nielsen, H. G. (2010). Samspil mellem praktik og teoretisk undervisning - kernen i professionsdidaktik (1. udgave, s. 25-40). Aarhus.

Levinsen, K., Ørngreen, R., \& Buhl, M. (2013). Telepresence as Educational Practice in the Third Teaching-Room: in Higher Music Education.

Mathiasen, H. (2011). Clickers, en læringsunderstøttende ressource? Dansk Universitetspædagogisk Tidsskrift, 11, 26-31.

Meyer, B. (2015). Learning through telepresence with iPads: placing schools in local/global communities. Interactive Technology and Smart Education, 12(4), 270-284.

Meyer, B., Jensen, M. P., Schleicher, A. B., \& Zoë, S. (2017). Student Activity in Blended Learning Environments : A Sociomaterial Perspective.

Meyer, H. (2005). Hvad er god undervisning? (1. udgave). København: Gyldendal. 
Nortvig, A. (2014). E-Learning in Poly-Topic Settings. The Electronic Journal of eLearning, 12(2), 206-214.

Nortvig, A., Christiansen, R., Karlsen, A., Spante, M., \& Wicke, K. (2015).

Grænser, barrierer og broer. Computermedieret kommunikation og kulturmøder i synkrone online arbejdsfællesskaber. I M. Engebretsen (Red.), Det tredje språket: mulitmodale studier av interkulturell kommunikasjon i kunst, skole og samfunnsliv (s. 267-281). Portal Forlag.

Nystrand, M. (1997). Opening dialogue: understanding the dynamics of language and learning in the English classroom. New York: Teachers College Press.

Nystrand, M., Wu, L. L., Gamoran, A., Zeiser, S., \& Long, D. A. (2003). Questions in Time: Investigating the Structure and Dynamics of Unfolding Classroom Discourse. Discourse Processes, 35(2), 135-198.

Rehn, N., Maor, D., \& McConney, A. (2017). Navigating the challenges of delivering secondary school courses by videoconference. British Journal of Educational Technology, 48(3), 802-813.

Scarbrough, J. E. (2015). Synchronous Videoconferencing in Distance Education for Pre-Licensure Nursing. Journal of Education and Training Studies, 3(4), 68-72.

VIA University College. (2015). Anvendelse af it i uddannelserne.

Wang, Q., Quek, C. L., \& Hu, X. (2017). Designing and Improving a Blended Synchronous Learning Environment: An Educational Design Research. The International Review of Research in Open and Distributed Learning, 18(3). 
Weitze, C., \& Ørngreen, R. (2014). The Global Classroom Model Simultaneous Campus-and-home-based Education Using Videoconferencing. The Electronic Journal of eLearning s, 215-226 SRC-GoogleScholar.

Ørngreen, R., Jørgensen, A. N., \& Noesgaard, S. S. (2016). Mobile probes: A scaffold for local learning with online resources? I H. H. Anne-Mette Nortvig, Birgitte Holm Sørensen, Morten Misfeldt, Rikke Ørngreen, Benjamin Allsopp, Birgitte Henningsen (Red.), Proceedings of the 5th International Conference on Designs for Learning (s. 283-299). Aalborg: Aalborg Universitetsforlag.

Ørngreen, R., Levinsen, K., Jelsbak, V. A., Bendsen, T., \& Møller, K. L. (2013). Live videotransmitteret undervisning. Tidsskriftet Læring og Medier (LOM), 6(11). 